DOI: http://doi.org/10.22585/hospdomic.v6i1.153

\title{
Home Hospital and Health Education: Legal documentation analysis pre COVID
}

\section{Hospital a Domicilio y Educación para la Salud: análisis legislativo pre COVID}

Das Dores, Ricardo' (1) 0000-0002-4725-4492

Clara, Ana Rita² (1) 0000-0002-5587-0842

1. Universidad de Huelva, Facultad de Educación, Psicología y Ciencias del Deporte. Huelva, España.

2. Centro Hospitalar Universitário Lisboa Central, Lisboa, Portugal.

Correspondencia/Correspondence

Ricardo das Dores

ricardo.m.a.dores@gmail.com

Recibido/Received

06.01 .2022

Aceptado/Accepted

10.01.2022
Conflicto de Intereses/Competing interest

There is no conflict of interest.

Financiación/Funding

Study conducted without funding

Contribuciones de autoría/Author contributions

All authors have contributed equally.

CÓMO CITAR ESTE TRABAJO | HOW TO CITE THIS PAPER

Das-Dores R, Clara AR. Home Hospital and Health Education: Legal documentation analysis pre COVID. Hosp Domic. 2022;6(1):37-45. 


\section{RESUMEN}

Introducción: La Hospitalización Domiciliaria es una alternativa válida y competente al internamiento clásico. No obstante, a pesar de contar con una existencia desde el siglo XX, solo recientemente fue una opción concreta para los pacientes del Serviço Nacional de Saúde. La educación para la salud y la alfabetización en salud son criterios fundamentales para un ejercicio de ciudadanía plena y acceso a cuidados de salud.

Método: Estudio de análisis documental basada en una revisión de los documentos legales (leys) de los últimos cinco años (2015-2020) y relacionado con la hospitalización domiciliaria y alfabetización en salud y educación para la salud. Al final se realizó un análisis discursivo de los documentos elegidos.

Resultados: Un total de 27 documentos resultaron de la búsqueda en el website del Diário da República Portuguesa Online. Dentro de este, 3 eran del Ministério da Saúde y su alcance era la Hospitalización Domiciliaria. El análisis discursivo demostró que no hay énfasis en el soporte legal para la Hospitalización Domiciliaria y sus unidades sobre la educación para la salud o alfabetización en salud.

Conclusiones: La educación para la salud y la alfabetización en salud son promotores de comportamientos saludables y el conocimiento puede servir para manejar enfermedades crónicas. La Hospitalización Domiciliaria maneja, mayoritariamente, enfermos con condiciones crónicas en fase aguda. La Hospitalización Domiciliaria es un contexto importante para desarrollar procesos de educación para la salud y promoción de la alfabetización en salud. Es fundamental que la documentación que regula el funcionamiento de la Hospitalización Domiciliaria tenga suporte para intervenciones para la promoción de la alfabetización y educación para la salud.

Palabras clave: Servicios de Atención de Salud a Domicilio; Educación en Salud; Comunicación en Salud; Alfabetización para la Salud.

\section{ABSTRACT}

Introduction: Hospital from home $(\mathrm{HH})$ is a valid and stable alternative to the conventional hospital admission. Although it has been used since early XX century only recently was implemented in Portugal, on the public sector. Health literacy is a sine qua non condition to exercise of citizenship and informed consenting.

Method: document analysis based on a review process of public legal documents from the last 5 years related with the implementation of $\mathrm{HH}$ and the development and role that health literacy plays on the process on $\mathrm{HH}$. A discourse analysis was undertaken after documents gathering.

Results: a total of 27 documents were recovered from the Portuguese public legal database (Diário da República Portuguesa). From those, a total of 3 versed $\mathrm{HH}$. Discourse analysis presented the lack of emphasis on health literacy on the documents and, thus, on the legal fundamentals of implementation of $\mathrm{HH}$ units.

Conclusions: Health literacy is a key element to included individuals on their health seeking behaviors and to manage their own health balance. Thus, to accept a different kind of hospital admission (when conditions are met) individuals should be provided with fundamental tools to overcome and develop their health literacy and to have an informed decision and consenting. Health literacy and health education are the core of $\mathrm{HH}$ units and, therefore, should be present on the discourse that establishes the units implementation on a legal basis.

Keywords: Home Care Services; Health Education; Health Communication; Health Literacy. 


\section{INTRODUCTION}

Home Hospital $(\mathrm{HH})$ or hospital at home are concepts that are associated with an alternative to traditional hospital inpatient admittance. The first experience appears in the 40's in New York's Montefiore Hospital where, to promote quality of care and provide extra space for patients, it is put into practice the first sketch of home hospital ${ }^{(1-3)}$. In Europe the first $\mathrm{HH}$ experience takes place in France, in 1957, and consistently during the 60's it spreads out through the continent ${ }^{(2,3)}$. It only arrives to Portugal in 2015 with the first Home Hospital unit is created at Hospital Garcia da Orta, Lisbon. In 2018 Centro Hospitalar de Vila Nova de Gaia/Espinho starts another HH unit(4). From 2019 onwards the development of several $\mathrm{HH}$ units was promoted. Nowadays the presence of $\mathrm{HH}$ units is unanimous on the majority of Portuguese public hospitals.

Home Hospital units aim to promote quality healthcare similar to conventional inpatient in hospital settings admittance with the possibility of reducing associated risks: crossed infections, falls, acute confusion, etc. Additionally the possibility for a patient to be receiving high quality healthcare in his home promote an environment that prompts healing conditions and better psychological conditions for the patient ${ }^{(4)}$.

The main features that constitute the core of a $\mathrm{HH}$ unit are the commitment to substitute completely an inpatient acute hospital admission; offers and provides the same level of care that would be provided in-hospital; it provides care that is commonly provided in a acute hospital and not in usual community based home care services ${ }^{(1)}$.

Health Literacy is of paramount importance for the development and quality life-styles and based on knowledge, personal skills and confidence ${ }^{(5)}$ : "Health literacy represents the cognitive and social skills which determine the motivation and ability of individuals to gain access to, understand and use information in ways which promote and maintain good health".

Home Hospital depends greatly on informal caregivers and/or family members support while patient is admitted to $\mathrm{HH}$. Their support is composed on early warning signs of deterioration, vital signs observations and recording, non-IV medication monitoring, administration and recording and a variety of data required to be provided to healthcare professionals when the visit is due. Health literacy must be one the components and should be a tool widely spread on legislation and official documents in order to be enforced by healthcare professionals. Health literacy is of paramount importance for the successful development of $\mathrm{HH}$. Therefore this retrospective descriptive study analyses the legal documentation related to $\mathrm{HH}$ issued by Portuguese health authorities in order to seek the relevance given to Health Literacy in this context.

\section{METHODS}

In order to develop this review and document analysis the authors established search on the website "Diário da República Electrónico - DRE' which is the online repository for Portuguese Legislation using the following terms: "hospitalização domiciliária" - between 01st January 2015 and 06th July 2020 and corresponding only to the "Ministério da Saúde" (Health Minister). A total of 27 documents were found containing the terms above mentioned and only 3 were considered for this review, after the title and purpose reading. Only laws or decree of laws were included in this search. 
Table 1. Search results and inclusion/exclusion criteria

\begin{tabular}{|c|c|c|}
\hline Law or decree of law & Inclusion criteria & Exclusion criteria \\
\hline $\begin{array}{l}\text { Aviso n. } .^{\circ} \text { 5078/2015 - Diário da República } \\
\text { n. }{ }^{\circ} \text { 89/2015, Série II de 2015-05-08 }\end{array}$ & & $\begin{array}{l}\text { Not Health Minister originated. } \\
\text { Not related to Home Hospital } \\
\text { Units. }\end{array}$ \\
\hline $\begin{array}{l}\text { Regulamento n. }{ }^{\circ} 742 / 2015 \text { - Diário da } \\
\text { República n. }{ }^{\circ} \text { 210/2015, Série II de 2015- } \\
\text { 10-27 }\end{array}$ & & $\begin{array}{l}\text { Not Health Minister originated. } \\
\text { Not related to Home Hospital } \\
\text { Units. }\end{array}$ \\
\hline $\begin{array}{l}\text { Aviso n. }{ }^{\circ} \text { 2718/2016 - Diário da República } \\
\text { n. }{ }^{\circ} \text { 42/2016, Série II de 2016-03-01 }\end{array}$ & & $\begin{array}{l}\text { Not Health Minister originated. } \\
\text { Not related to Home Hospital } \\
\text { Units. }\end{array}$ \\
\hline $\begin{array}{l}\text { Portaria n. } .^{\circ} \text { 165/2016 - Diário da República } \\
\text { n. }{ }^{\circ} 112 / 2016 \text {, Série I de 2016-06-14 }\end{array}$ & & $\begin{array}{l}\text { Not related to Home Hospital } \\
\text { Units. } \\
\text { Palliative care related. }\end{array}$ \\
\hline $\begin{array}{l}\text { Regulamento n. }{ }^{\circ} \text { 639/2016 - Diário da } \\
\text { República n. }{ }^{\circ} \text { 131/2016, Série II de 2016- } \\
07-11\end{array}$ & & $\begin{array}{l}\text { Not Health Minister originated. } \\
\text { Not related to Home Hospital } \\
\text { Units. }\end{array}$ \\
\hline $\begin{array}{l}\text { Regulamento n. }{ }^{\circ} \text { 973/2016 - Diário da } \\
\text { República n. }{ }^{\circ} \text { 206/2016, Série II de 2016- } \\
\text { 10-26 }\end{array}$ & & $\begin{array}{l}\text { Not Health Minister originated. } \\
\text { Not related to Home Hospital } \\
\text { Units. }\end{array}$ \\
\hline
\end{tabular}




\begin{tabular}{|c|c|c|}
\hline Law or decree of law & Inclusion criteria & Exclusion criteria \\
\hline $\begin{array}{l}\text { Regulamento n. }{ }^{\circ} \text { 596/2017 - Diário da } \\
\text { República n. }{ }^{\circ} \text { 220/2017, Série II de } 2017 \text { - } \\
\text { 11-15 }\end{array}$ & & $\begin{array}{l}\text { Not Health Minister originated. } \\
\text { Not related to Home Hospital } \\
\text { Units. }\end{array}$ \\
\hline $\begin{array}{l}\text { Portaria n. }{ }^{\circ} 66 / 2018 \text { - Diário da República } \\
\text { n. }{ }^{\circ} 46 / 2018 \text {, Série I de 2018-03-06 }\end{array}$ & & $\begin{array}{l}\text { Not related to Home Hospital } \\
\text { Units. } \\
\text { Palliative care related. }\end{array}$ \\
\hline $\begin{array}{l}\text { Aviso n. }{ }^{\circ} \text { 3063/2018 - Diário da República } \\
\text { n. }{ }^{\circ} 47 / 2018 \text {, Série II de 2018-03-07 }\end{array}$ & & $\begin{array}{l}\text { Not Health Minister originated. } \\
\text { Not related to Home Hospital } \\
\text { Units. }\end{array}$ \\
\hline $\begin{array}{l}\text { Deliberação (extrato) n. }{ }^{\circ} 561 / 2018 \text { - Diário } \\
\text { da República n. }{ }^{\circ} 88 / 2018 \text {, Série II de 2018- } \\
\text { 05-08 }\end{array}$ & & $\begin{array}{l}\text { Not Health Minister originated. } \\
\text { Not related to Home Hospital } \\
\text { Units. }\end{array}$ \\
\hline $\begin{array}{l}\text { Despacho n. } .^{\circ} 7219 / 2018 \text { - Diário da } \\
\text { República n. }{ }^{\circ} \text { 145/2018, Série II de 2018- } \\
\text { 07-30 }\end{array}$ & & $\begin{array}{l}\text { Not Health Minister originated. } \\
\text { Not related to Home Hospital } \\
\text { Units. }\end{array}$ \\
\hline $\begin{array}{l}\text { Despacho n. }{ }^{\circ} 8807 / 2018 \text { - Diário da } \\
\text { República n. }{ }^{\circ} \text { 179/2018, Série II de 2018- } \\
\text { 09-17 }\end{array}$ & $\begin{array}{l}\text { Home Hospital national } \\
\text { coordination election. }\end{array}$ & \\
\hline $\begin{array}{l}\text { Despacho n. }{ }^{\circ} 9323-A / 2018 \text { - Diário da } \\
\text { República n. } 191 / 2018,1^{\circ} \text { Suplemento, } \\
\text { Série II de 2018-10-03 }\end{array}$ & $\begin{array}{l}\text { Home Hospital units: } \\
\text { national implementation } \\
\text { strategy. }\end{array}$ & \\
\hline
\end{tabular}




\begin{tabular}{|c|c|c|}
\hline Law or decree of law & Inclusion criteria & Exclusion criteria \\
\hline $\begin{array}{l}\text { Lei n. }{ }^{\circ} \text { 70/2018 - Diário da República n.․ } \\
\text { 251/2018, Série I de 2018-12-31 }\end{array}$ & & $\begin{array}{l}\text { Not Health Minister originated. } \\
\text { Not related to Home Hospital } \\
\text { Units. }\end{array}$ \\
\hline $\begin{array}{l}\text { Despacho n. } 3721 / 2019 \text { - Diário da } \\
\text { República n. }{ }^{\circ} \text { 66/2019, Série II de 2019- } \\
\text { 04-03 }\end{array}$ & & $\begin{array}{l}\text { Not related to Home Hospital } \\
\text { Units. } \\
\text { Palliative care related. }\end{array}$ \\
\hline $\begin{array}{l}\text { Deliberação n. }{ }^{\circ} 616 / 2019 \text { - Diário da } \\
\text { República n. }{ }^{\circ} \text { 98/2019, Série II de } 2019 \text { - } \\
\text { 05-22 }\end{array}$ & & Staff nomination. \\
\hline $\begin{array}{l}\text { Resolução do Conselho de Ministros n. } \\
82 / 2019 \text { - Diário da República n. }{ }^{\circ} \text { 100/2019, } \\
\text { Série I de 2019-05-24 }\end{array}$ & & Staff nomination. \\
\hline $\begin{array}{l}\text { Resolução do Conselho de Ministros n. } \\
\text { 99/2019 - Diário da República n. }{ }^{\circ} \text { 119/2019, } \\
\text { Série I de 2019-06-25 }\end{array}$ & & Staff nomination. \\
\hline $\begin{array}{l}\text { Resolução do Conselho de Ministros n. }{ }^{\circ} \\
\text { 129-A/2019 - Diário da República n. } \\
\text { 146/2019, } 1^{\circ} \text { Suplemento, Série I de 2019- } \\
\text { 08-01 }\end{array}$ & & Staff nomination. \\
\hline $\begin{array}{l}\text { Despacho n. }{ }^{\circ} 7871 / 2019 \text { - Diário da } \\
\text { República n. }{ }^{\circ} 171 / 2019 \text {, Série II de } 2019 \text { - } \\
\text { 09-06 }\end{array}$ & & $\begin{array}{l}\text { Miscellaneous physical resources } \\
\text { items. }\end{array}$ \\
\hline $\begin{array}{l}\text { Regulamento n. }{ }^{\circ} 743 / 2019 \text { - Diário da } \\
\text { República n. }{ }^{\circ} \text { 184/2019, Série II de 2019- } \\
\text { 09-25 }\end{array}$ & & Non-Health Minister originated. \\
\hline
\end{tabular}




\begin{tabular}{|c|c|c|}
\hline Law or decree of law & Inclusion criteria & Exclusion criteria \\
\hline $\begin{array}{l}\text { Deliberação n. }{ }^{\circ} \text { 1002/2019 - Diário da } \\
\text { República n. }{ }^{\circ} \text { 187/2019, Série II de 2019- } \\
\text { 09-30 }\end{array}$ & & Staff nomination. \\
\hline $\begin{array}{l}\text { Despacho n. }{ }^{\circ} \text { 9402/2019 - Diário da } \\
\text { República n. }{ }^{\circ} \text { 200/2019, Série II de 2019- } \\
\text { 10-17 }\end{array}$ & & Staff nomination. \\
\hline $\begin{array}{l}\text { Despacho n. }{ }^{\circ} \text { 12333/2019 - Diário da } \\
\text { República n. }{ }^{\circ} \text { 246/2019, Série II de 2019- } \\
\text { 12-23 }\end{array}$ & $\begin{array}{l}\text { Home Hospital } \\
\text { implementation } \\
\text { enhancement. }\end{array}$ & \\
\hline $\begin{array}{l}\text { Despacho n. }{ }^{\circ} \text { 1721/2020 - Diário da } \\
\text { República n. } 26 / 2020 \text {, Série II de 2020- } \\
\text { 02-06 }\end{array}$ & & Staff nomination. \\
\hline $\begin{array}{l}\text { Despacho n. }{ }^{\circ} \text { 3728/2020 - Diário da } \\
\text { República n. }{ }^{\circ} \text { 61/2020, Série II de 2020- } \\
\text { 03-26 }\end{array}$ & & Staff nomination. \\
\hline $\begin{array}{l}\text { Lei n. }^{\circ} \text { 2/2020 - Diário da República n. } \\
64 / 2020 \text {, Série I de 2020-03-31 }\end{array}$ & & $\begin{array}{l}\text { Not Health Minister originated. } \\
\text { Not related to Home Hospital } \\
\text { Units. }\end{array}$ \\
\hline
\end{tabular}

On the 3 documents above mentioned a discourse analysis ${ }^{(6)}$ was implemented following the "in-document" search of the terms: "literacy em saúde" (health literacy) AND/OR "educação para a saúde" (health education).

\section{RESULTS}

The 3 legislative documents versed Home Hospital units directly: on the 17th September 2018 is nominated the national coordinator responsible for the implementation of several Home Hospital Units throughout the country. Despite the fact that this document is mainly based on logistic details, the terms "educação para a saúde" and/or "literacia em saúde" were not presented nor mentioned in this document.

On the 03rd of October of 2018 the legal document number 9329-A/2018 describes the national strategy for Home Hospital Units implementation throughout several public hospitals in the country. The document enumerates the patient's rights and duties, medication and range of availability, units timetable and staffing, motoring and evaluation, human resources and main goals for Home Hospital units. The minister mandates the "Direcção Geral da Saúde" to produce the ground rules for Home 
Hospital units function. This document has no mention to "educação para a saúde" nor "literacia em saúde".

On the 23rd December of 2019 the legal document number 12333/2019 reinforces that all public hospitals should have a working Home Hospital Unit. This document has no mention to "educação para a saúde" nor "literacia em saúde".

Following the results above stated the author searched the "Direcção Geral da Saúde" (Directorate General Health) website for the ground rules or standard operation procedure (SOP) for portuguese Home Hospital Units: SOP 020/2018 regulates all the activities and healthcare delivered through these type of hospital admission. The SOP regulates criteria for patients inclusion/admission and refusal, diagnostic test and therapies expected too held in this type of admission, patients pathway, audit criteria and evaluation standards. Although this legal document is the pivotal for the development, regulation and daily healthcare deliver for Home Hospital units it has no mention to the expressions: "educação para a saúde" nor "literacia em saúde". However there is indication that healthcare professionals should teach and instruct - therefore promote literacy - to patient and main carer regarding treatment being delivered, infection control strategies and, as well, to promote knowledge development in healthcare professionals through research and/or academic placements.

\section{DISCUSSION}

Health literacy is a powerful asset that healthcare professionals may develop on their patients. Home Hospital units have the power to provide quality healthcare and decrease in hospital admission length of stay and improve patients quality of life ${ }^{(7)}$. If perceived has an asset that promotes healthy lifestyles and health seeking behaviors, health literacy can be portrayed has a powerful weapon to patients take control of their life on a healthy manner ${ }^{(8)}$. The implications on quality of life and costs savings are obvious. Empowering citizens to play an active role in improving their own health and to promote a health equity context is pivotal to abolish inequalities and disadvantages and marginalized societies $\left({ }^{5}\right.$.

Portugal is the country that, when compared to another European countries, presents the lowest percentage $(8,6 \%)$ of individuals with Excellent Health Literacy levels ${ }^{(8,9)}$. The European average percentage of individuals that possessed a Sufficient level of Health Literacy is $36 \%$ whereas in Portugal is $42,4 \%$. Portugal presents $38,1 \%$ of individuals with Problematic level of Health Literacy when compared with $35,2 \%$ of European average. The Inadequate level of Health Literacy is in Portugal of $10,9 \%$ whereas in Europe is $12,4 \%(8,9)$. The most vulnerable part of Portuguese population on Health Literacy levels are individuals with 65 or above years of age, low income and low degree of literacy, with chronic diseases, with a poor perception of their health status and with limitations due to chronic conditions ${ }^{(8,10)}$.

Health Literacy is a tool crucial to promote equity on healthcare access and maintenance of quality of life. Home Hospital units seek to deliver excellent healthcare to patients, avoid iatrogenic complications, reduce costs and avoid functional decline ${ }^{(1)}$. The range of pathologies that area admitted to Home Hospital is focus on chronic conditions and acute phase of chronic conditions. ${ }^{(8)}$ It is extremely important that the opportunity is seized to provide tailored healthcare to a patient when a admitted in Home Hospital setting and, as well, to establish a diagnosis and plan of intervention to overcome any possible needs on Health Literacy. Home Hospital is an emergent tool to provide Health Literacy tailored to patient needs in his own setting. These conditions are prosperous for a successful interaction and acquisition of knowledge. Additionally literature states that the majority of conditions that establish admissions to Home Hospital are chronic conditions ${ }^{(7)}$. How to manage 
chronic conditions and alarm signs are just two examples on how healthcare providers may promote Health Literacy on their patients. Although, with effort, one can withdraw an educational intention and inclination on the elaboration of the legal documents evaluated, this is not clear and explicit. The lack of Health Literacy dimension and wording on legal documents that support Home Hospital units regulation is presented on this analysis review. Additionally the relevance of Health Literacy on promoting equity on access to healthcare and decreasing the gap between marginalized individuals and health is well established. Therefore authors conclude that it is extremely important that legislative documentation provide support to healthcare professionals increase Health Literacy in their practice to individuals admitted in Home Hospital units.

\section{BIBLIOGRAFÍA}

1. Leff B, Montalto M. Home hospital-toward a tighter definition. J Am Geriatr Soc. 2004;52(12):2141. DOI: 10.1111/j.1532-5415.2004.52579_1.x

2. Cotta R, Suarez-Varela M. La Hospitalización Domiciliaria: antecedentes, situaciónn atual y perspectivas. Pam Am J Public Health. 2001;10(1):45-55.

3. Escarrabill J. La atención domiciliaria como alternativa a la hospitalización convencional. Aten Primaria. 2002;30(5):304-9.

4. Direcção Geral de Saúde. Hospitalização em Idade Adulta: Norma 020/2018 [Internet]. Lisboa, Portugal: Serviço Nacional de Saúde; 2018 [accessed January 10, 2021]. Available at https:// bit.ly/3td5IZX

5. World Health Organization (WHO). Health Promotion Glossary (WHO/HPR/HEP/98.1) [Internet]. Geneva, Switzerland: WHO; 1998 [accessed January 10, 2021]. Available at https://bit. ly/3FeTInP

6. Bogdan R, Biklen S. Investigação Qualitativa em Educação. Porto, Portugal: Porto Editora; 1994.

7. Gonçalves-Bradley DC, lliffe S, Doll HA, Broad J, Gladman J, Langhorne P, et al. Early discharge hospital at home. Cochrane Database Syst Rev. 2017;6(6):CD000356. DOI: 10.1002/14651858. CD000356.pub4

8. Direcção Geral da Saúde. Plano de Acção para a Literacia em Saúde Portugal 2019-2021 [Internet]. Lisboa, Portugal: Serviço Nacional de Saúde; 2019 [accessed January 10, 2021]. Available at https://bit.ly/3Gdlnpr

9. Sørensen K, Pelikan J, Rothlin F, Ganahl K, Slonska Z, Doyle G, et al; The HLS-EU Consortium. Health literacy in Europe: comparative results of the European health literacy survey (HLS-EU). Eur J Public Health. 2015;25(6):1053-8. DOI: 10.1093/eurpub/ckv043

10. Espanha R, Ávila P, Veloso-Mendes R. Literacia em Saúde em Portugal Relatório Síntese. Lisboa, Portugal: Fundação Calouste Gulbenkian; 2016. 